\title{
Direct Effects of Rat Growth Hormone on Rat Islets of Langerhans in Tissue Culture
}

\author{
P. G. Whittaker ${ }^{1}$ and K. W. Taylor ${ }^{2}$ \\ Biochemistry Group, School of Biological Sciences, University of Sussex, Brighton, England
}

Summary. The effects of rat growth hormone $(1 \mu \mathrm{g} /$ $\mathrm{ml}$ ) on the synthesis and release of insulin by isolated rat islets of Langerhans were studied. There was no effect of growth hormone on the release of insulin from freshly isolated islets during 30 min incubation periods. By contrast, islets previously cultured for $16 \mathrm{~h}$ with growth hormone exhibited a $40 \%$ increase in the release of insulin in response to glucose or to glucose and theophylline. These islets also showed specific increases in basal and glucose-stimulated insulin synthesis of $16 \%$ and $21 \%$ respectively, together with a $22 \%$ increase in the basal rate of total protein synthesis. The total insulin content of islets was not affected by culture with growth hormone. The adenylate cyclase activity of islet homogenates was unaffected by the presence of growth hormone during $30 \mathrm{~min}$ incubations. When homogenates from islets previously cultured with growth hormone were studied, basal adenylate cyclase activity was unchanged, while fluoride-stimulated adenylate cyclase activity was increased by $37 \%$. It is concluded that growth hormone can directly affect the synthesis and release of insulin in islets of Langerhans, without relation to its metabolic activities in other target organs.

Key words: Insulin release, insulin synthesis, protein synthesis, adenylate cyclase, pancreatic islets, tissue culture, growth hormone.

\footnotetext{
Present Addresses:

${ }^{1}$ MRC Human Reproduction Group, Princess Mary Maternity Hospital, Newcastle upon Tyne NE2 3BD, England

2 Biochemistry Department, London Hospital Medical College, Turner Street, London El 2AD, England
}

Growth hormone $(\mathrm{GH})$, has long been thought to affect the islets of Langerhans [1], and blood levels of insulin are known to be increased following growth hormone treatment in animals [2]. There has, however, been considerable controversy as to whether such effects are immediate or delayed. The balance of evidence favours a delayed response. Thus, islets isolated from hypophysectomised rats injected with growth hormone for some days, show increased rates of insulin synthesis and release by comparison with controls $[3,4,5,6,7,8]$.

By contrast, when growth hormone is incubated with isolated islets in vitro for up to three hours, it has been shown that there is no direct stimulation of insulin release $[4,9,10,11]$. This confirms studies using pancreatic pieces or whole pancreatic perfusion $[4,9,12,27]$, although here the acute stimulation of insulin release by $\mathrm{GH}$ has also been reported $[13,28$, 29].

In the present study, long term effects of growth hormone on islet function have been examined in an islet tissue culture system in order to exclude the influence of other tissues on $\beta$ cells.

\section{Materials}

\section{Reagents}

Radiochemicals were obtained from the Radiochemical Centre, Amersham, U.K. Collagenase, Hepes (4-(2-hydroxyethyl)piperazine-ethanesulphonic acid), and cyclic AMP came from Sigma (London) Chemical Co. Ltd., Kingston, Surrey, U. K. Insulin binding reagent and human insulin standards were supplied from Wellcome Reagents Ltd., Beckenham, Kent, U. K. Bovine serum albumin fraction V (B S A) came from Armour Pharmaceutical Co Ltd., Eastbourne, Sussex, U.K. Tissue culture medium 199, newborn calf serum, and Hanks basic salt solution were from Flowlabs Ltd., Irvine, Ayrshire, U. K. Glaxo Laboratories Ltd., Greenford, Middlesex, U. K. supplied penicillin 
Table 1. Release of insulin from isolated rat islets of Langerhans in the presence and absence of growth hormone. Rat islets were incubated, in groups of three, for $30 \mathrm{~min}$ in bicarbonate-buffered medium containing glucose or glucose and theophylline. Insulin release was then measured by immunoassay. Expt. 1: Freshly isolated islets were studied with or without rat $\mathrm{GH}(1 \mu \mathrm{g} / \mathrm{ml})$ added directly to the incubation medium. Expt. 2: Other islets were maintained in tissue culture medium, with or without rat GH $(1 \mu \mathrm{g} / \mathrm{ml})$, for $16 \mathrm{~h}$ prior to $30 \mathrm{~min}$ incubation

\begin{tabular}{|c|c|c|c|c|}
\hline & \multicolumn{2}{|c|}{ Incubation medium } & \multicolumn{2}{|c|}{ Insulin release $(\mathrm{ng} / \mathrm{islet} / 30 \mathrm{~min})$} \\
\hline & $\begin{array}{l}\text { Glucose } \\
\mathrm{mmol} / \mathrm{l}\end{array}$ & Additions & Control islets & $\begin{array}{l}\text { Islets directly } \\
\text { incubated with } \mathrm{GH}\end{array}$ \\
\hline Expt. 1 & $\begin{array}{r}5 \\
20 \\
20\end{array}$ & $\begin{array}{l}- \\
- \\
5 \mathrm{mmol} / 1 \text { theophylline }\end{array}$ & $\begin{array}{l}0.39 \pm 0.05(6) \\
1.25 \pm 0.16(6) \\
2.07 \pm 0.08(6)\end{array}$ & $\begin{array}{l}0.34 \pm 0.04(6) \\
1.32 \pm 0.15(6) \\
1.97 \pm 0.09(6)\end{array}$ \\
\hline Expt. 2 & $\begin{array}{r}5 \\
20 \\
20\end{array}$ & $\begin{array}{l}- \\
- \\
5 \mathrm{mmol} / \mathrm{l} \text { theophylline }\end{array}$ & $\begin{array}{l}0.48 \pm 0.06(18) \\
1.64 \pm 0.07(25) \\
2.14 \pm 0.15(15)\end{array}$ & $\begin{array}{l}0.67 \pm 0.08^{\mathrm{a}}(15) \\
1.88 \pm 0.09^{\mathrm{a}}(33) \\
3.01 \pm 0.33^{\mathrm{a}}(14)\end{array}$ \\
\hline
\end{tabular}

${ }^{a}$ Denotes values significantly different from corresponding control observations $(p<0.05)$. Results are shown as means \pm SEM. Numbers of observations are in parentheses

and streptomycin. Guinea-pig anti-insulin serum and normal guinea-pig serum was kindly donated by Dr. A. Bone of Sussex University. Rat growth hormone (GH-B-3) was obtained from the National Institute of Arthritis, Metabolism and Digestive Diseases (Ratks 7/69 GLI is still detectable but not 30K GLI. Therefore it is assumed that variations in $30 \mathrm{~K}$ GLI represent modifications of GLI of pancreatic origin $[15,23]$.

The sensitivity of the assay for $7 / 69$ GLI wad in $0.154 \mathrm{~mol} / 1$ saline, sterilized by filtration, and stored at $-20^{\circ}$ at a concentration of $200 \mu \mathrm{g} / \mathrm{ml}$ for one month.

\section{Animals}

Male Sprague-Dawley rats, 220-250 g, were used. They were allowed free access to food and water.

\section{Methods}

\section{Tissue Culture of Isolated Islets}

Islets were isolated from rat pancreases using collagenase digestion techniques $[14,15]$. The medium used for isolation was Hanks basic salt solution supplemented with $20 \mathrm{mmol} / 1$ Hepes, penicillin 100 units $/ \mathrm{ml}$, streptomycin $0.1 \mathrm{mg} / \mathrm{ml}$, and sodium bicarbonate $350 \mathrm{mg} / 1$. Some islets were studied immediately, while others were transferred to $5 \mathrm{~cm}$ plastic petri dishes. About 40 islets were placed in each dish, in a culture medium consisting of $4 \mathrm{ml}$ of tissue culture medium $199(\mathrm{pH} 6.9)$ supplemented with $20 \%$ (v/v) newborn calf serum, penicillin 100 units $/ \mathrm{ml}$ and streptomycin $0.1 \mathrm{mg} / \mathrm{ml}$. The glucose concentration was $5.6 \mathrm{mmol} / 1$. Some dishes also contained $25 \mu \mathrm{l}$ of rat $\mathrm{GH}$ in solution giving an initial concentration of $1 \mu \mathrm{g} / \mathrm{ml}$. The concentration of $\mathrm{GH}$, as assayed by a radioreceptor assay based on the method of Tsushima and Friesen [31], and specific for $\mathrm{GH}$, had fallen to $0.09 \mu \mathrm{g} / \mathrm{ml}$ after $16 \mathrm{~h}$ of culture [16]. The islets were maintained in an incubator at $37^{\circ} \mathrm{C}$, in a humidified atmosphere of air/ $\mathrm{CO}_{2}(95: 5)$. The tissue culture method [15] had been modified by the use of dishes to which the islets would not adhere but would remain free-floating [16]. Whilst this method allowed for the successful culture of islets for a week or more with good preservation of islet function, it was found that harvest after overnight culture yielded islets with the best sensitiv- ity to glucose stimulation. Therefore, after $16 \mathrm{~h}$, the islets were removed with a fine pasteur pipette and treated as described below.

\section{Determination of Insulin Release}

Freshly isolated or cultured islets were pre-incubated for $30 \mathrm{~min}$ at $37^{\circ}$ in a bicarbonate-buffered medium, $\mathrm{pH} \mathrm{7.4,} \mathrm{[17]} \mathrm{previously}$ gassed with $\mathrm{CO}_{2} / \mathrm{O}_{2}(5: 95)$ and containing bovine serum albumin $2 \mathrm{mg} / \mathrm{ml}$ and glucose $5 \mathrm{mmol} / \mathrm{l}$. Groups of three islets were then incubated for $30 \mathrm{~min}$ in $1 \mathrm{ml}$ of fresh bicarbonate-buffered medium containing various concentrations of glucose, and also $5 \mathrm{mmol} / 1$ theophylline when appropriate. Rat $\mathrm{GH}, 1 \mu \mathrm{g} / \mathrm{ml}$, was also present in some tubes in some experiments. After the incubation the medium was sampled and the concentration of insulin determined by radioimmunoassay [18], using human insulin standards. Rat GH is very unlikely to cross react in this assay. The rate of insulin release was expressed as the amount of insulin released per islet per $30 \mathrm{~min}$.

\section{Determination of the Biosynthetic Activity of Islets}

Incubation of Islets. Groups of ten cultured islets were incubated in tubes containing $0.2 \mathrm{ml}$ of bicarbonate-buffered medium, $\mathrm{pH} 7.4$, previously gassed with $\mathrm{CO}_{2} / \mathrm{O}_{2}(5: 95)$ and supplemented with bovine serum albumin $2 \mathrm{mg} / \mathrm{ml}$, and either $2 \mathrm{mmol} / 1$ or $20 \mathrm{mmol} / 1$ glucose, together with $10 \mu \mathrm{Ci}$ of $\mathrm{L}-\left(4,5-{ }^{3} \mathrm{H}\right)$ leucine per tube. The tubes were incubated with gentle shaking, for $1 \mathrm{~h}$ at $37^{\circ} \mathrm{C}$. After incubation, the islets were washed twice in $40 \mathrm{mmol} / 1$ phosphatebuffered saline (containing $1 \mathrm{mg} / \mathrm{ml} \mathrm{L}$-leucine, $\mathrm{pH}, 7.4$ ), and subsequently sonicated for $10 \mathrm{~s}$ in a further $150 \mu \mathrm{l}$ of the phosphatebuffered saline. These sonicates were diluted and frozen until needed for assay. The total insulin contents of the sonicated islets were later determined by radioimmunoassay.

Estimation of Rates of Insulin Synthesis. The newly synthesised labelled insulin and proinsulin were separated from the rest of the islet proteins by the incubation of diluted sonicates of islets with an excess of guinea-pig anti-insulin serum (AIS) coupled to cyanogen bromide-activated Sepharose (AIS-Sepharose) [19]. The antibodies used in this assay completely bind all insulin immunoreactive material, including proinsulin [20]. Normal guinea-pig serum (NGS) coupled to activated Sepharose (NGS-Sepharose) served as 
a control for the non-specific binding of labelled proteins to the Sepharose beads and serum. The non-specific absorption of NGSSepharose has been shown not to be identifiable with insulin or proinsulin $[19,20]$.

Immune Binding of Labelled Insulin. Duplicate $50 \mu \mathrm{l}$ samples of the diluted islet sonicates were placed in serum tubes. $200 \mu \mathrm{l}$ of either AIS- or NGS-Sepharose, and $800 \mu \mathrm{l}$ of the phosphate-buffered saline (supplemented with BSA $2 \mathrm{mg} / \mathrm{ml}$ ), were added to each tube and they were then mixed and rotated for $90 \mathrm{~min}$. After incubation, the Sepharose beads were washed with phosphatebuffered saline and solubilised overnight at room temperature in $0.8 \mathrm{ml}$ of Soluene 350 tissue solubiliser. Toluene scintillant $(8 \mathrm{ml})$ was then added and the vials counted.

Estimation of Total Protein Synthesis. Samples of $50 \mu 1$ (in duplicate) of each islet sonicate were mixed with $100 \mu \mathrm{l}$ of phosphatebuffered saline (containing BSA $5 \mathrm{mg} / \mathrm{ml}$ ) and the proteins were precipitated by the addition of $5 \%(\mathrm{w} / \mathrm{v})$ trichloroacetic acid. A blank containing only phosphate buffered saline with added BSA was always used. The precipitate was collected by centrifugation for $5 \mathrm{~min}$ at $2000 \mathrm{~g}$, then washed with $5 \%$ trichloroacetic acid and solubilised for $2 \mathrm{~h}$ in $0.8 \mathrm{ml}$ of Soluene. Scintillant $(8 \mathrm{ml})$ was added and the vials counted.

Expression of Results. Radioactivity incorporated into insulin was taken as the difference between the radioactivity bound to the AIS-Sepharose beads and the NGS-Sepharose beads. To correct for differences in size and insulin content of islets, the incorporation of ${ }^{3} \mathrm{H}$-leucine into protein was expressed as $\mathrm{cpm} / \mathrm{ng}$ total islet insulin content $/ \mathrm{h}$

\section{Measurement of Islet Adenylate Cyclase Activity}

Rat islets were isolated and homogenised in groups of 50 in $25 \mathrm{mmol} / 1 \mathrm{Tris} / \mathrm{HCl}$ buffer ( $\mathrm{pH} \mathrm{7.6)}$. Adenylate cyclase activity was then estimated by measuring the rate of formation of cyclic ${ }^{32} \mathrm{P}$-AMP from $\alpha^{32} \mathrm{P}-\mathrm{ATP}$ in $30 \mathrm{~min}$ incubations [21]. NaF $(10 \mathrm{mmol} / \mathrm{l})$ or rat $\mathrm{GH}(0.1$ and $1 \mu \mathrm{g} / \mathrm{ml})$ were present during the incubations as appropriate. After incubation and separation of the newly synthesised cyclic ${ }^{32} \mathrm{P}$-AMP from the reaction mixture by elution on alumina columns, the eluates were counted directly in a liquid scintillation counter. The protein concentration of each homogenate was measured colorimetrically [30], using crystalline bovine albumin standards. Adenylate cyclase activity was then expressed as pmol cyclic ${ }^{32} \mathrm{P}$-AMP formed/mg islet protein/ 30 min.

Statistical Treatment of Results. Results are expressed as means \pm SEM. The significance of differences between means was analysed by using Student's $t$ test.

\section{Results}

\section{Insulin Release and Total Insulin Content of Isolated Islets}

The insulin release of freshly-isolated islets, in response to $20 \mathrm{mmol} / \mathrm{l}$ glucose, was three times that in response to $5 \mathrm{mmol} / \mathrm{l}$ glucose, and a further stimulation was seen in the presence of $20 \mathrm{mmol} / 1$ glucose plus $5 \mathrm{mmol} / 1$ theophylline (Table 1 ). The addition of rat $\mathrm{GH}$ during the 30 minute incubation had no effect on basal or glucose stimulated insulin release. The insulin release from islets after $16 \mathrm{~h}$ of culture was comparable to that of freshly-isolated islets, save that the response to $20 \mathrm{mmol} / 1$ glucose was increased (Table 1). The presence of rat $\mathrm{GH}$ during the $16 \mathrm{~h}$ culture period significantly increased the amount of insulin subsequently released. However the total insulin content of the islets was not significantly affected. Thus, the mean insulin content for islets, cultured in a medium containing growth hormone, was $22.6 \pm 1.8 \mathrm{ng}$ insulin/islet as opposed to $20.2 \pm$ 1.2 for control islets $(n=16)$.

\section{Biosynthetic Activity of Isolated Islets}

After $16 \mathrm{~h}$ of culture, insulin synthesis showed a well preserved glucose sensitivity. Glucose at $20 \mathrm{mmol} / 1$ stimulated insulin synthesis $5.6 \times$ when compared to $2 \mathrm{mmol} / \mathrm{l}$ (i. e. basal) glucose (Table 2), and there was a corresponding 3-fold increase in total protein synthesis (Table 2). The presence of rat $\mathrm{GH}$ during culture was found to raise basal insulin synthesis and basal total protein synthesis significantly. When islets were incubated with $20 \mathrm{mmol} / \mathrm{l}$ glucose, insulin synthesis was significantly potentiated by rat $\mathrm{GH}$, while the glucose-stimulated total protein synthesis was unaffected.

Expressing these results in terms of insulin synthesis as a percentage of total protein synthesis, $20 \mathrm{mmol} / 1$ glucose caused the proportion of insulin synthesis in islets to increase to twice the basal level (Table 2). The increase in basal insulin synthesis due to rat $\mathrm{GH}$ was not statistically significant, but the ratio of insulin synthesis to total protein synthesis at $20 \mathrm{mmol} / 1$ glucose was significantly raised by rat $\mathrm{GH}$.

\section{Adenylate Cyclase Activity of Isolated Islets}

To determine whether long-term changes in insulin release or insulin biosynthesis may be mediated through an increase in islet adenylate cyclase activity, the activity of this enzyme in islet homogenates was studied. With freshly isolated islets, $10 \mathrm{mmol} / \mathrm{l} \mathrm{NaF}$ stimulated the adenylate cyclase activity to $3.5 \times$ the basal level (Table 3 ). The presence of rat $\mathrm{GH}$ during the 30 minute incubation however, did not significantly affect the basal adenylate cyclase activity, at either of the two concentrations used. The basal adenylate cyclase activity of islets cultured for $16 \mathrm{~h}$ was similar to that of freshly-isolated islets and there was a well-preserved response to stimulation by $\mathrm{NaF}$ (Table 3). Rat GH, present during the $16 \mathrm{~h}$ culture period, did not affect basal adenylate cyclase activity, but the response to $\mathrm{NaF}$ stimulation was significantly raised. 
Table 2. Insulin and total protein biosynthesis in isolated rat islets of Langerhans maintained in tissue culture in the presence and absence of growth hormone $(1 \mu \mathrm{g} / \mathrm{ml})$. After $16 \mathrm{~h}$, groups of 10 islets were incubated with ${ }^{3} \mathrm{H}$-leucine in a bicarbonate-buffered medium for $1 \mathrm{~h}$, and following sonication of the islets, the newly synthesised insulin and pro-insulin were isolated from the islet homogenates by a procedure utilising insulin antibody bound to Sepharose. Biosynthetic activity is expressed as the incorporation of ${ }^{3} \mathbf{H}$-leucine into protein. Total islet protein synthesis was determined by the precipitation of islet homogenates with trichloroacetic acid

\begin{tabular}{|c|c|c|c|c|c|c|}
\hline \multirow{2}{*}{$\begin{array}{l}\text { Addition to } \\
\text { incubation } \\
\text { medium } \\
\text { Glucose } \\
\text { mmol/1 }\end{array}$} & \multicolumn{2}{|c|}{$\begin{array}{l}\text { Incorporation into insulin } \\
(\mathrm{cpm} / \mathrm{ng} \text { total islet insulin } / \mathrm{h})\end{array}$} & \multicolumn{2}{|c|}{$\begin{array}{l}\text { Incorporation into total protein } \\
\text { (cpm/ng total islet insulin/h) }\end{array}$} & \multicolumn{2}{|c|}{$\begin{array}{l}\text { Ratio of incorporation into insulin to } \\
\text { incorporation into total protein }\end{array}$} \\
\hline & Control & $\begin{array}{l}\text { Islets previously } \\
\text { cultured with } \mathrm{GH}\end{array}$ & Control & $\begin{array}{l}\text { Islets previously } \\
\text { cultured with GH }\end{array}$ & $\begin{array}{l}\text { Control } \\
\%\end{array}$ & $\begin{array}{l}\text { Islets previously } \\
\text { cultured with } \mathrm{GH} \\
\%\end{array}$ \\
\hline 2 & $13.1 \pm 1.6$ & $17.7 \pm 1.4^{\mathrm{a}}$ & $123 \pm 8$ & $151 \pm 11^{\mathrm{a}}$ & $10.9 \pm 1.4$ & $12.6 \pm 1.2$ \\
\hline 20 & $73.8 \pm 4.5$ & $92.9 \pm 7.3^{\mathrm{a}}$ & $365 \pm 20$ & $366 \pm 21$ & $20.6 \pm 1.2$ & $25.0 \pm 1.1^{\mathrm{a}}$ \\
\hline
\end{tabular}

${ }^{a}$ Denotes significant difference from control $(\mathrm{p}<0.05)$. Results are given as the means \pm SEM of 11 observations

Table 3. Adenylate cyclase activity of isolated rat islets of Langerhans in the presence and absence of growth hormone. Rat islets were isolated and homogenised in groups of 50 in Tris $/ \mathrm{HCl}$ buffer. Adenylate cyclase activity was then estimated by measuring the rate of formation of cyclic ${ }^{32} \mathrm{P}$-AMP from $\alpha^{32} \mathrm{P}-\mathrm{ATP}$ in $30 \mathrm{~min}$ incubations. Expt. 1: Freshly-isolated islets were studied with rat $\mathrm{GH}$ or $\mathrm{NaF}$ added to the incubation medium. Results are means \pm SEM of 3 observations. Expt. 2: Other isolated islets were main tained in tissue culture medium, with or without rat GH $(1 \mu \mathrm{g} / \mathrm{ml})$, for $16 \mathrm{~h}$ prior to their $30 \mathrm{~min}$ incubation. Results expressed as mean $\pm S E M$ of 5 observations

\begin{tabular}{|c|c|c|}
\hline $\begin{array}{l}\text { Additions to incu- } \\
\text { bation medium }\end{array}$ & \multicolumn{2}{|c|}{$\begin{array}{l}\text { Cyclic }{ }^{32} \mathrm{P}-\mathrm{AMP} \text { formed }(\mathrm{pmol} / \mathrm{mg} \text { islet } \\
\text { protein } / 30 \mathrm{~min} \text { ) }\end{array}$} \\
\hline Expt. 1 & \multicolumn{2}{|l|}{$\begin{array}{l}\text { Freshly isolated } \\
\text { islets }\end{array}$} \\
\hline None & \multirow{4}{*}{\multicolumn{2}{|c|}{$\begin{array}{r}7.8 \pm 0.8 \\
8.0 \pm 2.8 \\
7.2 \pm 1.7 \\
28.9 \pm 2.4\end{array}$}} \\
\hline $\mathrm{GH} 0.1 \mu \mathrm{g} / \mathrm{ml}$ & & \\
\hline $\mathrm{GH} 1 \mu \mathrm{g} / \mathrm{ml}$ & & \\
\hline $\mathrm{NaF} 10 \mathrm{mmol} / \mathrm{l}$ & & \\
\hline Expt. 2 & $\begin{array}{l}\text { Cultured islets (no } \\
\text { GH) }\end{array}$ & $\begin{array}{l}\text { Islets previously } \\
\text { cultured with } \mathrm{GH}\end{array}$ \\
\hline None & $7.9 \pm 0.6$ & $8.5 \pm 0.7$ \\
\hline $\mathrm{NaF} 10 \mathrm{mmol} / 1$ & $23.0 \pm 1.5$ & $31.8 \pm 2.8^{\mathrm{a}}$ \\
\hline
\end{tabular}

a Significantly different from control, $(\mathrm{p}<0.05)$

\section{Discussion}

\section{Short-term Action of Growth Hormone on Insulin Release in Islets}

The finding that rat $\mathrm{GH}$ will not directly affect the insulin release of freshly-isolated islets within 30 minutes (Table 1) agrees with many earlier studies already mentioned. The observation that basal islet adenylate cyclase activity is unaffected by rat $\mathrm{GH}$ in the short term (Table 3 ) is also consistent with this. These two findings also indicate that the levels of adrenocorticoptropin and thyroid-stimulating hormone are negligible in the rat GH preparation used here. These two pituitary hormones have been shown to stimulate insulin release and islet adenylate cyclase directly in the short term in vitro [22]. It is concluded that over such a period of time, growth hormone at the concentration used is without direct effects on the release mechanism.

By contrast, there is evidence that $\mathrm{GH}$ may directly stimulate insulin biosynthesis, $[5,9,23]$ although there has been one report of no significant stimulation [10]. The positive effects possibly arise by $\mathrm{GH}$ influencing both the translation of messenger RNA and the transport of amino acids into islets [23]. Similar effects have also been seen in studies of the action of $\mathrm{GH}$ in vitro on protein synthesis in muscle [24]. Whether the increased insulin synthesis is a specific effect in relation only to insulin or part of a generally increased rate of protein synthesis is not yet clear.

Despite the lack of a rapid effect of intact growth hormone on insulin release reported in these studies, some recent work has strongly suggested that synthetic peptides containing $\mathrm{C}$-terminal sequences of growth hormone may produce a more immediate and direct effect on islets [26]. Furthermore, a factor closely associated with growth hormone, but not identical with it, may also stimulate insulin release in perifused islets of hypophysectomised rats, while purified, intact, human $\mathrm{GH}$ will not [11]. In the light of these observations the question also arises as to whether or not growth hormone is being modified in the tissue culture to a more biologically active material. This question cannot at present be answered with any certainty.

\section{Long-term Action of Growth Hormone on Islets in Tissue Culture}

Insulin release (Table 1), and islet adenylate cyclase activity (Table 3 ) are shown to be functionally wellpreserved in islets recovered after culture for $16 \mathrm{~h}$. In 
addition, the responses of insulin and total protein synthesis to glucose (Table 2), compare well with the responses seen in freshly-isolated islets [20]. The culture system is therefore an adequate one for the study of direct action of $\mathrm{GH}$ on islets.

Table 2 shows that islet protein synthesis, and insulin synthesis in particular, are both stimulated (an effect already noted in short term experiments). The responses of insulin release to both low and high glucose concentrations are also raised, which implies an increase in islet sensitivity to glucose stimulation (Table 1). It is possible that some of the influence of $\mathrm{GH}$ on insulin release is a result of the stimulation of basal protein synthesis in islets, and further study of the onset of potentiation of insulin release and the relationship of insulin synthesis is needed. However, in general, long-term changes in insulin release, due to glucose or hormonal variation, are often mediated through changes in islet adenylate cyclase activity [25]. Over a period of time, raised levels of cyclic AMP lower the threshold concentration at which glucose becomes effective, and potentiate the response to stimulatory glucose concentrations. The results in Table 1 can be given this interpretation and furthermore, it can be seen that theophylline is more effective in potentiating the glucose-stimulated insulin release of those islets cultured with rat GH than that of the control islets. If rat $\mathrm{GH}$ did act in the longterm via increased adenylate cyclase activity then its effect on insulin release would be more readily demonstrable in the presence of theophylline (which inhibits cyclic AMP breakdown). However, the study of islet adenylate cyclase activity itself did not entirely confirm this hypothesis. Rat $\mathrm{GH}$ raised the response of adenylate cyclase to $\mathrm{NaF}$ stimulation (Table 3), which indicates an increase in the total amount of adenylate cyclase present in the islets [25], but did not cause an increase in the basal activity of the system (Table 3). Clarification of the role of cyclic AMP in the action of GH must await the direct measurement of cyclic AMP levels and protein kinase activity in islets after culture with $\mathrm{GH}$.

It has sometimes been assumed that growth hormone by acting as an insulin antagonist will raise blood glucose which in turn will affect islet activity so that its effect on the islets are indirect. The experiments reported here have clearly indicated that even though this effect is delayed, growth hormone must directly affect the islets of Langerhans. They should therefore be considered as a major target organ for its activity.

Acknowledgements. We thank Dr. S. L. Howell for valuable discussion and advice. Financial support from the Medical Research Council and the British Diabetic Association is gratefully acknowledged. P. G. W. was an M. R. C. research scholar.

\section{References}

1. Young FG (1939) The relation of the anterior pituitary gland to carbohydrate metabolism. Br Med J II: 393-396

2. Randle PJ, Young FG (1956) The influence of pituitary growth hormone on plasma insulin activity. J Endocrinol 13: 335-348

3. Martin J M, Gagliardino J J (1967) Effect of growth hormone on the isolated islets of Langerhans. Nature 213: 630-631

4. Malaisse W J, Malaisse-Lagae F, King S, Wright PH (1968) Effect of growth hormone on insulin secretion. Am J Physiol 215: 423-428

5. Sun A M, Lin BJ, Haist RE (1972) Studies on the effects of growth hormone and thyroxine on proinsulin synthesis and insulin formation in the islets of Langerhans in the rat. Can J Physiol Pharmacol 50: 1147-1151

6. Schatz H, Katsilambros N, Hinz M, Voigt KH, Nierle C, Pfeiffer EF (1973) Hypophysis and function of pancreatic islets. The effect of substitution with GH and ACTH on insulin secretion and biosynthesis of insulin and proinsulin in isolated pancreatic islets of hypophysectomised rats. Diabetologia 9: $140-144$

7. Parman A U (1975) Effects of hypophysectomy and short term growth hormone replacement on insulin release from and glucose metabolism in isolated rat islets of Langerhans. J Endocrinol 67: 1-17

8. Parman AU (1975) Changes in insulin content of insulin and RNA synthesis in isolated rat islets of Langerhans after hypophysectomy and short-term growth hormone replacement. J Endocrinol 67: 19-28

9. Taylor KW (1969) Biosynthesis of insulin. In: Gual C, Ebling FJG (eds) Progress in endocrinology: Proceedings of the Third International Congress of Endocrinology, Mexico. Int. Congr. Series No. 184. Excerpta Medica Foundation, Amsterdam, p 220-224

10. Schatz H, Maier V, Hinz M, Schleyer M, Nierle C, Pfeiffer EF, (1973) Secretion and biosynthesis of insulin in isolated pancreatic islets of intact and hypophysectomised rats in the presence of growth hormone, corticotrophin and human chorionic somatotrophin in vitro. Horm Metab Res 5: 29-33

11. Larson B A, Williams TL, Lewis UJ, VandeLaan WP (1978) Insulin secretion from pancreatic islets: effects of growth hormone and related proteins. Diabetologia 15: 129-132

12. Coore HG, Randle PJ (1964) Regulation of insulin secretion studied with pieces of rabbit pancreas incubated in vitro. Biochem J 93: 66-78

13. Tai T-Y, Pek S (1976) Direct stimulation by growth hormone of glucagon and insulin release from isolated rat pancreas. Endocrinology 99: 669-677

14. Howell SL, Taylor KW (1968) Potassium ions and the secretion of insulin by islets of Langerhans incubated in vitro. Biochem J 108: 17-24

15. Anderson A, Hellerström C (1972) Metabolic characterisation of isolated pancreatic islets in tissue culture. Diabetes 21: 546-554

16. Whittaker PG (1977) Tissue culture of islets of Langerhans and the study of the direct effects of growth hormone on islet function. D. Phil. Thesis, University of Sussex, Brighton, p 119-121

17. Gey GO, Gey MK (1936) The maintenance of normal hormone cells and tumor cells in continuous culture. Am J Cancer 27: $45-76$

18. Hales CN, Randle PJ (1963) Immunoassay of insulin with insulin antibody precipitate. Biochem J 88: 137-146

19. Berne C (1975) Anti-insulin serum coupled to sepharose 4B as a tool for the investigation of insulin biosynthesis in the B-cells of obese hyperglycaemic mice. Endocrinology 97: 1241-1247

20. Bone A J, Howell S L (1977) Alterations in regulation of insu- 
lin biosynthesis in pregnancy and starvation studied in isolated islets of Langerhans. Biochem J 166: 501-507

21. Howell SL, Montague W (1973) Adenylate cyclase activity in isolated rat islets of Langerhans. Effects of agents which alter rate of insulin secretion. Biochim Biophys Acta 320: 44-52

22. Malaisse W J, Malaisse-Lagae F, Mayhew D (1967) A possible role for the adenylate system in insulin secretion. J Clin Invest 46: 1724-1734

23. Sun AM, Haist RE (1975) On the mechanism of the stimulatory effects of growth hormone on proinsulin and insulin biosynthesis. In: International Symposium on growth hormone and related peptides, Milan, Italy. University of Milan, p 26

24. Kostyo J L, Rillema J A (1971) In vitro effects of growth hormone on the number and activity of ribosomes engaged in protein synthesis in isolated rat diaphragm. Endocrinology 88: 1054-1062

25. Montague W, Howell S L (1975) Cyclic AMP and the physiology of the islets of Langerhans. In: Greengard P, Robson G A, (eds) Advances in cyclic nucleotide research, 6. Raven Press, New York, p 201-243

26. Weernsinghe C, Bornstein J (1978) Effects of synthetic Cterminal fragments of $\mathrm{HGH}$ on insulin release by isolated islets. Am J Physiol 234: E527-E531
27. Grodsky GM, Bennett L, Batts A, McWilliams N, Vcella C (1962) Insulin secretion from isolated perfused pancreas. Fed Proc 21: 202

28. Bouman R P, Bosboom R S (1965) Effects of growth hormone and of hypophysectomy on the release of insulin from rat pancreas in vitro. Acta Endocrinol (Kbh) 50: 202-212

29. Curry D L, Bennett L L, Li CH (1974) In vitro enhancement of insulin secretion by growth hormone. Biochem Biophys Res Commun 60: 146-149

30. Lowry AL, Rosebrough NJ, Farr AL, Randall RJ (1951) Protein measurement with the folin phenol reagent. J Biol Chem 193: 265-275

31. Tsushima T, Friesen HG (1973) Radioreceptor assay for growth hormone. J Clin Endocrinol Metab 37: 334-337

Received: March 3, 1979,

and in revised form: November 9, 1979

Dr. P. G. Whittaker

MRC Human Reproduction Group

Princess Mary Maternity Hospital

Newcastle upon Tyne NE2 3BD

England 